\title{
Effects of location and time of Pinctada margaritifera spat transfer from hatchery, on its growth and mortality in the sea
}

\begin{abstract}
This study reports on the effects of different locations and hatchery transfer time on the growth and mortality of P. margaritifera spat. In the first experiment spat of P. margaritifera were transferred to the sea farms in Hendurabi and Lavan Islands at 25, 50, and 65 days post settlement and a Control was kept in the hatchery. Retaining spat in the hatchery more than 25 days after settlement did not improve the growth and mortality of juveniles. Spat grown in Hendurabi were significantly greater in size compared to those grown in hatchery and Lavan at the end of experiment $(\mathrm{P}<0.05)$. Growth curve both in hatchery and sea farms best conformed to cubic model. In the second experiment, 55 days old spat from two propagation trials at a size circa $0.5 \mathrm{~mm}$ were deployed to the Hendurabi on 5th September and 7th October 2008 and were reared for five months accordingly. Spat of first deployment were significantly greater in size than second deployment at the end of experiment $(\mathrm{P}<0.05)$. Maximum $(0.34 \mathrm{~mm} \mathrm{~d}-1)$ and minimum $(0.11 \mathrm{~mm} \mathrm{~d}-1)$ daily growth rate (DGR) were observed in September and October 2008 respectively. Mean DGR in fall was more than double in winter. There was positive correlation between water temperature and DGR, whereas food abundance, as expressed by concentration of chlorophyll-a, had a negligible effect.
\end{abstract}

Keyword: Hatchery, Pinctada margaritifera, Spat, Daily growth rate, Temperature 